\title{
EDITORIAL
}

\section{Ten Years On: Rethinking Transnational Environmental Law}

This issue brings to a close the first full decade of Transnational Environmental Law (TEL). It is sobering to consider the shape of the world in 2011 and to remember our ignorance of the events to come. The global stage is always a roiling mix of disparate forces, but between the ascendance of the populist right, COVID-19, Brexit, the rise and decline (and rise?) of ISIS, and the ongoing escalation of climate-related emergencies, it seems that TEL's initial ten years witnessed more than their share of global turmoil. In strictly legal terms there were unexpected developments that became core areas of relevance to this journal. The emergence of environmental litigation in China, for example, has been a striking shift, the magnitude of which could not easily have been foreseen at TEL's inception. ${ }^{1}$ The 'rights of nature' as a feature of legislation and constitutional law, though emergent in the 2000s, has bubbled to the surface in additional jurisdictions over the last decade, ${ }^{2}$ and the Paris Agreement ${ }^{3}$ marked a significant departure from earlier approaches to climate change under international law. ${ }^{4}$

1 See, e.g., Q. Gao \& S. Whittaker, 'Standing to Sue Beyond Individual Rights: Who Should Be Eligible to Bring Environmental Public Interest Litigation in China?' (2019) 8(2) Transnational Environmental Law, pp. 327-47; Y. Zhao, S. Lyu \& Z. Wang, 'Prospects for Climate Change Litigation in China' (2019) 8(2) Transnational Environmental Law, pp. 349-77; X. He, 'Legal and Policy Pathways of Climate Change Adaptation: Comparative Analysis of the Adaptation Practices in the United States, Australia and China' (2018) 7(2) Transnational Environmental Law, pp. 347-73; He, n. 9 below; and Xie \& Xu, n. 20 below.

2 See, e.g., L. Schimmöller, 'Paving the Way for Rights of Nature in Germany: Lessons Learnt from Legal Reform in New Zealand and Ecuador' (2020) 9(3) Transnational Environmental Law, pp. 569-92; E. O'Donnell et al., 'Stop Burying the Lede: The Essential Role of Indigenous Law(s) in Creating Rights of Nature' (2020) 9(3) Transnational Environmental Law, pp. 403-27; M. Tănăsescu, 'Rights of Nature, Legal Personality, and Indigenous Philosophies' (2020) 9(3) Transnational Environmental Law, pp. 429-53; Martuwarra RiverOfLife et al., 'Recognizing the Martuwarra's First Law Right to Life as a Living Ancestral Being' (2020) 9(3) Transnational Environmental Law, pp. 541-68; E. Macpherson, J. Torres Ventura \& F. Clavijo Ospina, 'Constitutional Law, Ecosystems, and Indigenous Peoples in Colombia: Biocultural Rights and Legal Subjects' (2020) 9(3) Transnational Environmental Law, pp. 521-40; P. Villavicencio Calzadilla \& L.J. Kotzé, 'Living in Harmony with Nature? A Critical Appraisal of the Rights of Mother Earth in Bolivia' (2018) 7(3) Transnational Environmental Law, pp. 397-424; L.J. Kotzé \& P. Villavicencio Calzadilla, 'Somewhere between Rhetoric and Reality: Environmental Constitutionalism and the Rights of Nature in Ecuador' (2017) 6(3) Transnational Environmental Law, pp. 401-33; A. Staker, 'Should Chimpanzees Have Standing? The Case for Pursuing Legal Personhood for Non-Human Animals' (2017) 6(3) Transnational Environmental Law, pp. 485-507; S. Borràs, 'New Transitions from Human Rights to the Environment to the Rights of Nature' (2016) 5(1) Transnational Environmental Law, pp. 113-43; and Jolly \& Menon, n. 27 below.

3 Paris (France), 12 Dec. 2015, in force 4 Nov. 2016, available at: https://unfccc.int/sites/default/files/english_paris_agreement.pdf.

4 See, e.g., A. Zahar, 'Collective Obligation and Individual Ambition in the Paris Agreement' (2020) 9(1) Transnational Environmental Law, pp. 165-88; B. Lewis, 'The Rights of Future Generations within the Post-Paris Climate Regime' (2018) 7(1) Transnational Environmental Law, pp. 69-87; L. Wegener, 'Can 
The present issue of TEL affords an opportunity to examine these developments anew, and to revisit critically the conclusions of prior scholarship. We begin in China.

\section{RETHINKING ENVIRONMENTAL LITIGATION IN CHINA}

Litigation is a fascinating and critical mechanism of social change. Whereas protest movements strive to bring about legislative or administrative change through widespread shifts in public opinion, litigation campaigns rely principally on pre-existing doctrinal, statutory, or constitutional commitments that have been ignored or implemented incompletely. Successful campaigns thus depend on the authority and independence of the judiciary, and on a degree of sustained judicial resilience sufficient to outlast or overcome opposing political forces. ${ }^{5}$ Courts must both be willing to rule against the governing regime and have the authority to order efficacious remedies. These attributes are typically associated with rule-of-law values and with a robust doctrine of separation of powers. Even in the United States (US), ordinarily regarded as exemplary in these respects, successful litigation campaigns are few and far between and contingent on other forms of public support. ${ }^{6}$ Court-based actions in these areas have been welcomed and encouraged by some - for example, judicial calls for 'climate conscious lawyering" ${ }^{7}$ - but also have been met with trepidation by others, who consider the often unelected, and democratically unaccountable, position of judges a disqualifying feature in the light of the types of decision needed in these cases. ${ }^{8}$

Competence and legitimacy constraints on court authority are all the more apparent in China, where, as Xiangbai He explains, judicial power 'is still susceptible to the overarching authority of the Chinese Communist Party (CCP) in many respects'. ${ }^{9}$ Scholars who seek indications of judicial activism in China must have a trained eye, for judicial independence 'is not something that simply exists or does not exist ${ }^{\text {'0 }}$ but instead 'requires a more nuanced discussion'. ${ }^{11}$ Nonetheless, many legal scholars have noted

the Paris Agreement Help Climate Change Litigation and Vice Versa?' (2020) 9(1) Transnational Environmental Law, pp. 17-36; B. Mayer, 'International Law Obligations Arising in relation to Nationally Determined Contributions' (2018) 7(2) Transnational Environmental Law, pp. 251-75.

5 See M. McCann, 'Law and Social Movements: Contemporary Perspectives' (2006) 2 Annual Review of Law and Social Science, pp. 17-38.

6 See, e.g., G. Rosenberg, The Hollow Hope: Can Courts Bring About Social Change? $2^{\text {nd }}$ edn (University of Chicago, 2008).

7 J. Preston, 'Climate Conscious Lawyering' (2021) 95(1) Australian Law Journal, pp. 51-66. See also M.H. Ousley, 'Precedent, Politics, or Priorities: Are Courts Stepping Out of Their Traditional Judicial Bounds when Addressing Climate Change?' (2019) 25(2) Hastings Environmental Law Journal, pp. 349-74.

8 See, e.g., F. Smith, 'Undemocratic Restraint' (2017) 70(3) Vanderbilt Law Review, pp. 845-916.

9 X. He, 'Mitigation and Adaptation through Environmental Impact Assessment Litigation: Rethinking the Prospect of Climate Change Litigation in China' (2021) 10(3) Transnational Environmental Law, pp. 413-39, at 419.

10 J. Cohen, 'The Chinese Communist Party and “Judicial Independence": 1949-1959' (1969) 82(5) Harvard Law Review, pp. 967-1006, at 972. See also R. Peerenboom (ed.), Judicial Independence in China: Lessons for Global Rule of Law Promotion (Cambridge University Press, 2010).

11 He, n. 9 above, p. 420. 
that environmental litigation is a growing force within China. ${ }^{12}$ In this issue of TEL, two articles critically examine trends in litigation aimed at environmental policy change. Several relatively recent, oft-heralded developments - the rise of public interest litigation and of tort actions related to climate change - receive a fresh re-examination, one that is not uniformly enthusiastic.

In the first of these articles, Xiangbai He examines climate change litigation in China to argue that both scholarly attention and activists' resources may be misplaced. ${ }^{13}$ For the most part, litigants and scholars curious about climate litigation in China - including authors in this journal - have argued or assumed that tort actions are the primary way forward. ${ }^{14}$ Successful tort claims, after all, typically obligate polluters to pay damages and thus help to internalize the social costs of pollution. ${ }^{15}$ This internalization function comes about directly through successful claims, or indirectly as similarly situated entities act pre-emptively to avoid similar claims. Especially in the climate context, it is this indirect effect that is sought, yet no such effect will arise if there is not a plausible risk of liability in the first place.

He argues that tort liability for climate-related harm is unlikely to materialize given the current state of the law in China. There are several sizeable hurdles. Firstly, as in other countries (including the US), several doctrines of tort law act as nearly insuperable obstacles to tort liability for climate-related injuries. Standing doctrine, in China as elsewhere, requires climate claimants to demonstrate that their private rights have been directly affected by the greenhouse gas (GHG) emissions of a particular defendant. ${ }^{16}$ Tort law also requires plaintiffs to establish a tight causal link between such emissions and a particular instance of climate-related damage. Even in settings favourable to plaintiffs, such showings are exceedingly difficult. ${ }^{17}$ Moreover, beyond these doctrinal concerns are the political and institutional challenges associated with the economic power exerted by state-owned enterprises in the Chinese system, the most likely targets of tort litigation. In his contribution He argues that courts 'will inevitably consider public policy concerns' before ordering such enterprises to abate emissions outside established energy policy and emissions regimes. ${ }^{18}$

Setting aside tort law, He contends that a more promising path can be found in administrative litigation, and specifically in the law of environmental impact assessment (EIA). Since its inception, EIA law has been faulted for its emphasis on procedure

12 See Gao \& Whittaker, n. 1 above; and Zhao, Lyu \& Wang, n. 1 above.

13 He, n. 9 above.

14 See, e.g., Zhao, Lyu \& Wang, n. 1 above.

15 Cf. Milieudefensie et al. v. Royal Dutch Shell Plc, District Court of The Hague, 26 May 2021, C/09/571932/HA ZA 19-379 (in which the Court imposed specific reduction obligations on RDS rather than award damages to the plaintiffs).

16 He, n. 9 above, p. 435.

17 Although for notable exceptions see Milieudefensie v. Shell, n. 15 above, and The State of the Netherlands (Ministry of Economic Affairs and Climate Policy) v. Stichting Urgenda, Supreme Court of The Hague, ECLI:NL:HR:2019:2007.

18 He, n. 9 above, p. 437. 
and its lack of substantive demands. ${ }^{19}$ Rather than require specific environmental outcomes or forms of remediation, EIA law requires the compilation and dissemination of information. Nonetheless, given that GHG analyses have only recently and sporadically been incorporated into project reviews, EIA litigation could meaningfully improve decision making on climate-related matters. Unlike tort, in administrative litigation standing rules have been relaxed in China to allow public interest litigation. EIA processes also provide an opportunity for coordination when multiple environmental concerns conflict; litigation could help to ensure that climate concerns are given appropriate attention. He notes that EIA law at present lacks a specific reference point from which to assess the adequacy of GHG controls, but that courts could order administrative bodies to employ carbon intensity reduction targets that would establish a de facto policy for other parties.

In the second article in this pair, Lei Xie and $\mathrm{Lu} \mathrm{Xu}$ examine environmental public interest litigation (EPIL) in China. ${ }^{20}$ The rise of EPIL in recent years is part of a larger trend: the Chinese government has invited increased public participation as it shifts towards more decentralized modes of governance to maintain social control and monitor diffuse local governments. ${ }^{21}$ Throughout the 2010s, various reforms allowed EPIL suits to be brought both by non-governmental organizations (NGOs) and by the procuratorate. $^{22}$ EPIL by NGOs has been regarded as a positive development for environmental affairs, but Xie and $\mathrm{Xu}$ sound several notes of caution.

Firstly, the authors note that NGOs are dependent on government action in several respects. A sizeable portion of EPIL by NGOs comes about after a procurator provides evidence or other assistance. This is fine so far as it goes, but there are numerous provinces where procuratorates are inactive. Xie and Xu find that NGOs are similarly inactive in those areas, and they observe that a rise in ecological damage litigation brought by local governments could delay or displace further EPIL by NGOs, ${ }^{23}$ as EPIL litigation is typically suspended during a compensation action. Relatedly, NGOs often piggyback on administrative actions previously brought against polluters. The authors relate several examples in which NGOs initiated EPIL only many months after hefty administrative penalties were imposed on polluters. In these examples the NGOs succeeded in winning judgments, but the magnitude of those judgments paled in comparison with the earlier penalties and, arguably, added little by way of deterrent value. ${ }^{24}$

Secondly, Xie and $\mathrm{Xu}$ assert that NGOs have made imprudent litigation decisions that could lead to reputational or financial distress. They point primarily to unwise financial risks in bringing EPIL. Far from surefire victory, NGOs can be left on the hook for court fees, which escalate in proportion to the damages sought. The authors

19 J. Sax, 'The (Unhappy) Truth about NEPA' (1973) 26(2) Oklahoma Law Review, pp. 239-48.

20 L. Xie \& L. Xu, 'Environmental Public Interest Litigation in China: A Critical Examination' (2021) 10(3) Transnational Environmental Law, pp. 441-65.

21 X. Zhu \& K. Wu, 'Public Participation in China's Environmental Lawmaking: In Pursuit of Better Environmental Democracy' (2017) 29(3) Journal of Environmental Law, pp. 389-416.

22 Xie \& Xu, n. 20 above, pp. 447-50.

23 Ibid., p. 452.

24 Ibid., pp. 453-6. 
note several instances in which NGOs avoided financial disaster only because the court reduced its fees or awarded attorney's fees to the NGO despite losing the claim. ${ }^{25}$ They relate also several cases of questionable judgment related to efforts of NGOs to secure a favourable jurisdiction for EPIL.

In sum, environmental litigation in China is still in its infancy, and growing pains are to be expected. Litigation will undoubtedly play a substantial role in a mature and effective system of environmental governance, but the precise contours of that role in China have yet to be worked out. In the interim, these articles highlight obstacles that could drain scarce resources spent on strategic litigation to further environmental causes in China.

\section{RETHINKING THE RIGHTS OF NATURE}

The establishment of legal rights for non-human natural entities has taken flight in recent years, and has generally been welcomed by scholars. ${ }^{26}$ The contribution by Stellina Jolly and Roshan Menon continues this exploration but injects a note of caution about recent developments in India, and urges ongoing refinement of the doctrine in this area. ${ }^{27}$

The analysis by Jolly and Menon focuses on two 2017 judgments issued by the Uttarakhand High Court (UtK HC). In the Ganga case, the UtK HC held that the river Ganga was a legal living entity. ${ }^{28}$ It rendered this holding without an express request from the petitioner, who merely sought full implementation of an earlier court order. In the Glacier case, shortly thereafter, the same court applied the Ganga reasoning to hold that the Himalayas and its glaciers and streams were also juristic persons 'on a par with the river Ganga'. ${ }^{29}$ Both rulings have been stayed by the Supreme Court of India but remain binding on the lower courts within Uttarakhand during the stay. ${ }^{30}$ The authors predict that the holding regarding legal personhood will survive review. ${ }^{31}$

From one vantage point, these cases mark the advent of a new mechanism for environmental protection in India, a mechanism already being employed in other judicial and legislative chambers across the country. ${ }^{32}$ The authors acknowledge that the doctrinal change 'marks a step forward in jurisprudence', 33 and they express hope that a

25 Ibid., pp. 456-60.

26 See, e.g., sources at n. 2 above.

27 S. Jolly \& K.S.R. Menon, 'Of Ebbs and Flows: Understanding the Legal Consequences of Granting Personhood to Natural Entities in India’ (2021) 10(3) Transnational Environmental Law, pp. 467-92.

28 Mohammed Salim v. State of Uttarakhand, Writ Petition (PIL) No. 126 of 2014 (HC), 20 Mar. 2017 (Ganga).

29 Lalit Miglani v. State of Uttarakhand, 2017 SCC OnLine Utt 392 (Glaciers); an alternative citation is 2017 SCC Online Utt 367. See Jolly \& Menon, n. 27 above, p. 469.

30 Jolly \& Menon, n. 27 above. p. 474.

31 Ibid., p. 471.

32 Ibid., pp. 474-5.

33 Ibid., p. 491. 
'carefully constructed framework' of operationalization would indeed be 'a potent tool for ecological sustainability'. 34

Yet, there are clear philosophical and practical problems. Jurisprudentially, the authors take issue with the basis for the Ganga and Glacier decisions. The UtK HC articulated several rationales for granting personhood to natural features, but foremost among them was the religious and spiritual importance of those features. 'The use of religion as a rationale', write Jolly and Menon, 'sits uncomfortably within the secular legal system of India'. ${ }^{35}$ Rather than deplore the degraded environmental quality of the Ganga river and the violations of law that produced such a state, the UtK HC analyzed Hindu beliefs and practice, 'thereby making environmental protection subservient to the religious beliefs'. ${ }^{36}$ Even non-sacred rivers demand protection, but the twin decisions leave little doctrinal space for expansion in that direction. Furthermore, certain religious practices may be ecologically harmful; the law may need to preserve a means by which such practices can be made to yield to environmental protection. ${ }^{37}$

At a practical level, Jolly and Menon fault the UtK HC for appointing state officials, rather than independent or representative bodies, to protect natural resources. Given the competing demands of national law, such officials can be expected to face numerous conflicts of interest, and the authors warn that the new arrangement could merely replicate earlier environmentally destructive outcomes. They contend that the court could have improved its work by conducting a more fulsome investigation of the many other jurisdictions that have gravitated towards a rights of nature approach. As it stands, they note that existing legal tools - specifically, the polluter pays principle and the public trust doctrine - could perhaps have been employed to more useful effect in the Ganga and Glacier cases. ${ }^{38}$

\section{RETHINKING TREATIES AND TRANSNATIONAL LAW}

The final trio of articles in this issue return to a core theme in TEL - namely, the expansion of environmental governance beyond traditional legal instruments and across conventional lines of jurisdiction. This expansion is the very essence of environmental transnationalism, and each of these articles deals with the continuing evolution of transnational environmental law.

The inclusion in the Paris Agreement of non-state actors (NSAs) is a key example of this expansion. The Agreement is renowned for its novel bottom-up approach and its reliance on voluntary emissions reductions, but this approach risks the erosion of public international authority. ${ }^{39}$ In her article Charlotte Streck argues that NSAs, and specifically transnational partnerships among various NSAs, should be more formally

34 Ibid., p. 482.

35 Ibid., p. 476.

36 Ibid., p. 478.

37 Ibid., pp. 478-9.

38 Ibid., pp. 489-91.

39 D. Ciplet \& J.T. Roberts, 'Climate Change and the Transition to Neoliberal Environmental Governance' (2017) 46 Global Environmental Change, pp. 148-56. 
incorporated into the Paris framework. ${ }^{40}$ As Streck has previously noted, transnational partnerships have been growing in scope, ambition and visibility, and their centrality to the climate challenge is indisputable. ${ }^{41}$ From the Tropical Forest Alliance to the Carbon Neutral Cities Alliance, these partnerships are simultaneously an occasion for hope and a cause for concern. They 'catalyz[e] the energy and the ability to innovate and implement', yet they are 'plagued by concerns over a lack of legitimacy' and 'have been accused of eroding state governance'. ${ }^{42}$ Streck puts it well: 'Where forms of governance dominated by non-state interests lead to a scaling back of mandatory regulation and a privatization of environmental resources, the resulting regime may well be biased towards private concerns and fail to consider the needs of developing countries and vulnerable populations'. 43

Streck's solution relies on the flexibility of the Paris Agreement, and specifically Article 6, to create a formal framework to increase the accountability and transparency of transnational partnerships. ${ }^{44}$ In its terms and structure, the Agreement clearly envisions a sizeable role for NGOs, financial institutions, private entities, subnational governments, and so forth. ${ }^{45}$ Streck's proposed framework would flesh out this role by formulating 'ground rules' for climate engagement. The Secretariat of the United Nations Framework Convention on Climate Change ${ }^{46}$ would be empowered to screen partnerships according to defined eligibility criteria, to orchestrate activities across private and public spheres, and even to sanction underperforming partnerships with derecognition. The result would be an enhanced platform for collaborative engagement, brokered financial arrangements, accounting and accountability, and shortand long-term monitoring.

In certain respects the Paris Agreement itself represents 'a diplomatic response to a world that is increasingly shaped by a multitude of actors and initiatives', that is, by transnational governance. ${ }^{47}$ Interestingly, at the very time the Agreement was being negotiated, another international initiative was birthed by a similar (indeed, overlapping) group of actors in response to similar forces. The International Solar Alliance (ISA) is the subject of Vyoma Jha's study. ${ }^{48}$ Jha provides something of a behind-the-scenes look at the creation of a new, treaty-based international organization at a time when the efficacy of 'hard law' approaches was very much at issue. The ISA

40 C. Streck, 'Strengthening the Paris Agreement by Holding Non-State Actors Accountable: Establishing Normative Links between Transnational Partnerships and Treaty Implementation' (2021) 10(3) Transnational Environmental Law, pp. 493-515.

41 C. Streck, 'Filling in for Governments? The Role of the Private Actors in the International Climate Regime’ (2020) 17(1) Journal for European Environmental \& Planning Law, pp. 5-28.

42 Streck, n. 40 above, pp. 500-1.

43 Ibid., p. 501.

44 Ibid., pp. 510-12.

45 Ibid., pp. 497-8.

46 New York, NY (US), 9 May 1992, in force 21 Mar. 1994, available at: https:/unfccc.int/resource/docs/ convkp/conveng.pdf.

47 Streck, n. 40 above, p. 499.

48 V. Jha, "Soft Law in a Hard Shell": India, International Rulemaking and the International Solar Alliance' (2021) 10(3) Transnational Environmental Law, pp. 517-41. 
was launched by India and France in the shadow of the Paris climate talks in late 2015. Among its objectives are to coordinate and harmonize solar energy development and deployment, especially among 'solar-rich' equatorial countries. Jha's rich analysis relies on her interviews with stakeholders present at the creation of the ISA.

The ISA presents a puzzle in that it 'contains no explicit or implicit compliance mechanisms ${ }^{49}$ and lacks 'any explicit provision for financial or technology transfer'. ${ }^{50}$ Thus, it is unclear why India and France would insist upon a formal treaty, and unclear why poorer, developing countries would perceive any advantage in joining. This is in microcosm a core question posed by transnational governance, and Jha gives us an intriguing answer, one which turns largely on matters of political economy. She posits firstly that part of the puzzle can be explained by India's oft-noted desire to assert a leadership role in global governance, ${ }^{51}$ and indeed the ISA 'burnishe[d] India's clean energy credentials on the international stage. ${ }^{52}$ More interestingly, the ISA also served the domestic interests of Prime Minister Modi, whose policy platform included aggressive action on climate change. Movement towards this goal also answered to India's economic interests; a key objective was to expand target markets for the solar energy industry through economies of scale. Jha's account thus exposes the permeable boundary between soft- and hard-law approaches, and serves as a useful lens on the decision space of public officials during a time of profound global flux.

The final article in this issue is by Arron Honniball. ${ }^{53}$ It takes a fresh look at an archetypal global commons: ocean fisheries. For decades, states have struggled to address the vagaries of illegal, unreported, and unregulated (IUU) fishing, using a variety of legal and administrative approaches. A key challenge for any legal question related to the oceans, of course, is that of jurisdiction. Under both international and domestic law, IUU fishing is variously regulated by flag states, coastal states, port states, market states, and states of nationality - and to the extent that those states differ (as is typical), complicated questions arise. What happens when a governing entity - in this case the European Union (EU) - seeks to become a global leader in combating IUU fishing? How can that entity project its power across the various relevant lines of jurisdiction? Honniball details the EU's procedural efforts to identify and address non-cooperating third countries and argues that, as a matter of practice, the EU exploits its leverage to put pressure on third countries to augment their use of personality-based jurisdiction. This practice persists even though the relevant EU regulation offers no explicit basis for it.

The right of states to exercise extraterritorial, personality-based jurisdiction is not in doubt; nor is the general obligation in international fisheries law to 'exercise sufficient jurisdiction' to implement treaty provisions. ${ }^{54}$ The EU has kept its own house in order

49 Ibid., p. 526.

50 Ibid., p. 527.

51 Ibid., p. 529.

52 Ibid., p. 532.

53 A.N. Honniball, 'Engaging Asian States on Combating IUU Fishing: The Curious Case of the State of Nationality in EU Regulation and Practice' (2021) 10(3) Transnational Environmental Law, pp. 543-69.

54 Ibid., p. 547. 
in this respect: it has 'laid considerable groundwork for Member States to regulate their nationals involved in IUU fishing, ${ }^{55}$ but can the EU compel other states to exercise jurisdiction based on state of nationality? Here, Honniball explores the EU identification procedure for non-cooperating third countries, a procedure which results in the issuance of a 'Yellow Card' when the European Commission finds that a state is failing to discharge its duties under international law. Football enthusiasts will not be surprised to learn that further non-cooperation results in a 'Red Card'; sanctions may include trade restrictions. Given the size of the EU market, it is perhaps unsurprising that this scheme has 'resulted in notable successes', including 'enhanced prescriptive and enforcement jurisdiction being exercised by third countries' with regard to IUU fishing. ${ }^{56}$ Despite the fact that, under EU rules, states cannot be sanctioned solely for their failure to exercise sufficient jurisdiction over their nationals, the Commission has pressed a number of Asian states to adopt active, personality-based enforcement measures. Those states have generally responded, leading Honniball to conclude that 'the strong correlation between EU Yellow Cards, specific EU requests on regulating nationals, and third-country legislative amendments are indicative of the identification procedure playing an influential role'. 57 The EU, it seems, has been able to 'chisel away at state discretion' in this important area of environmental concern. ${ }^{58}$

\section{TEL EDITORIAL BOARD DEVELOPMENTS}

There are several changes to the TEL Editorial team to be announced.

Foremostly, this issue marks the last for our beloved colleague, co-Editor-in-Chief Veerle Heyvaert. A co-founder of this journal, Veerle has been a consummate leader and a wise and indefatigable steward for its mission. Her vision, enthusiasm, patience, and superhuman energy and perseverance have been a model for us all. Many of the articles that have filled these pages owe their polish and poignance to Veerle's sharp eye and generous interventions. It is difficult to imagine TEL without her, and we wish her all the best in her future pursuits - and we hope and expect to see her scholarship continue to appear in TEL. This issue contains a brief reflection to mark the end of her term, and TEL's tenth anniversary. The lone bright spot in this announcement is that Veerle will be replaced by longtime TEL editor Josephine van Zeben. We cannot think of a better person to guide this journal, along with co-founder Editor-in-Chief Thijs Etty, into its second decade.

It is a time for more goodbyes and hellos in the editorial team. Jacqueline Peel will step down as TEL editor at the end of this year. We are grateful for her support during these past years and are delighted that she will join TEL's Advisory Board, along with Veerle. In turn, Neil Gunningham will end his term on the Advisory Board, on which he has served since TEL's inception, to enjoy his well-deserved emeritus status.

\footnotetext{
55 Ibid., p. 552.

56 Ibid., p. 554.

57 Ibid., p. 566.

58 Ibid., p. 567.
} 
At the same time, we are delighted to announce two new TEL Editorial Board members, though by no means new to the TEL team: Leslie-Anne Duvic-Paoli and Anna Huggins have both served as TEL Assistant Editors for years before taking on this new role.

New Assistant Editors will take their place in the coming months, starting with Chiara Macchi (Wageningen University, The Netherlands). As Aaron Wu completes his four-year term as Assistant Editor, we thank him for his service and wish him all the best with his future endeavours.

Of course, anniversaries are also times for celebration. It is most gratifying to mark TEL's first decade with a higher than ever Impact Factor, increased to 3.424 for 20192020 (five-year Impact Factor 3.342), making TEL the highest ranking environmental law journal in both the law journals and environmental studies journals categories of the Clarivate Journal Citation Reports (JCR). This continued positive trend for TEL in these and other citation index rankings and usage metrics is a wonderful compliment and motivation for the entire TEL team, as well as our reviewers and, above all, our contributors.

Finally, we are excited to announce the launch of the annual TEL Best Article Prize. Starting with TEL volume 11, at the end of each year the TEL Editorial Board will select the most innovative and thought-provoking contribution published in TEL that year. The author(s) of the winning article will receive an award of $£ 250$ in Cambridge University Press books, the winning article (as well as two honourable mentions) will be made freely available to read for one year, and the author(s) of the winning submission and the two honourable mentions will receive a complimentary one-year journal subscription. Further details will be announced via TEL's homepage.

As always, we are grateful to our contributors, reviewers, TEL team members and, last but not least, our readers for making TEL such a vibrant scholarly community.

Editors-in-Chief

Thijs Etty

Veerle Heyvaert

Editors

Cinnamon Carlarne

Bruce Huber Jacqueline Peel

Josephine van Zeben 